\title{
The ProUSER2.0 Toolbox: Genetic Parts and Highly Customizable Plasmids for Synthetic Biology in Bacillus subtilis
}

Falkenberg, Kristoffer Bach; Mol, Viviënne; De La Maza Larrea, Arrate Sainz; Pogrebnyakov, Ivan; Nørholm, Morten H.H.; Nielsen, Alex Toftgaard; Jensen, Sheila Ingemann

\section{Published in:}

ACS Synthetic Biology

Link to article, DOI:

10.1021/acssynbio.1c00130

Publication date:

2021

Document Version

Publisher's PDF, also known as Version of record

Link back to DTU Orbit

Citation (APA):

Falkenberg, K. B., Mol, V., De La Maza Larrea, A. S., Pogrebnyakov, I., Nørholm, M. H. H., Nielsen, A. T., \& Jensen, S. I. (2021). The ProUSER2.0 Toolbox: Genetic Parts and Highly Customizable Plasmids for Synthetic Biology in Bacillus subtilis. ACS Synthetic Biology, 10(12), 3278-3289.

https://doi.org/10.1021/acssynbio.1c00130

\section{General rights}

Copyright and moral rights for the publications made accessible in the public portal are retained by the authors and/or other copyright owners and it is a condition of accessing publications that users recognise and abide by the legal requirements associated with these rights.

- Users may download and print one copy of any publication from the public portal for the purpose of private study or research.

- You may not further distribute the material or use it for any profit-making activity or commercial gain

- You may freely distribute the URL identifying the publication in the public portal 


\title{
The ProUSER2.0 Toolbox: Genetic Parts and Highly Customizable Plasmids for Synthetic Biology in Bacillus subtilis
}

\author{
Kristoffer Bach Falkenberg, ${ }^{\dagger}$ Viviënne Mol, ${ }^{\dagger}$ Arrate Sainz de la Maza Larrea, Ivan Pogrebnyakov, \\ Morten H. H. Nørholm, Alex Toftgaard Nielsen, and Sheila Ingemann Jensen*
}

Cite This: ACS Synth. Biol. 2021, 10, 3278-3289

Read Online

\section{ACCESS | Llll Metrics \& More | 回 Article Recommendations | (s) Supporting Information}

ABSTRACT: Versatile DNA assembly standards and compatible, well-characterized part libraries are essential tools for creating effective designs in synthetic biology. However, to date, vector standards for Gram-positive hosts have limited flexibility. As a result, users often revert to PCR-based methods for building the desired genetic constructs. These methods are inherently prone to introducing mutations, which is problematic considering vector backbone parts are often left unsequenced in cloning workflows. To

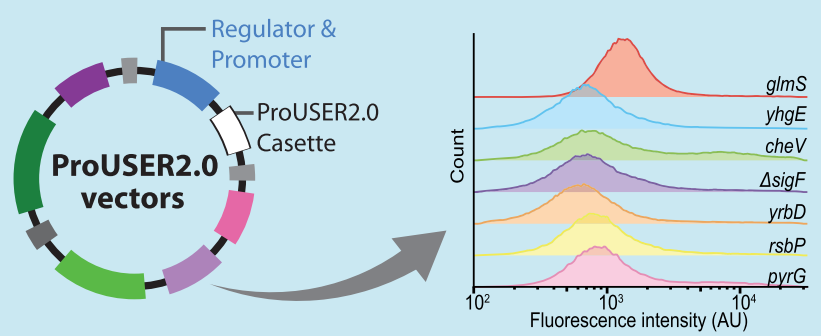
circumvent this, we present the ProUSER2.0 toolbox: a standardized vector platform for building both integrative and replicative shuttle vectors forBacillus subtilis. The ProUSER2.0 vectors consist of a ProUSER cassette for easy and efficient insertion of cargo sequences and six exchangeable modules. Furthermore, the standard is semicompatible with several previously developed standards, allowing the user to utilize the parts developed for these. To provide parts for the toolbox, seven novel integration sites and six promoters were thoroughly characterized in B. subtilis. Finally, the capacity of the ProUSER2.0 system was demonstrated through the construction of signal peptide libraries for two industrially relevant proteins. Altogether, the ProUSER2.0 toolbox is a powerful and flexible framework for use in B. subtilis.

KEYWORDS: gram-positive, Bacillus subtilis, synthetic biology, standardization, protein expression

\section{COPYEDITING LEVEL: 2}

\section{INTRODUCTION}

The Gram-positive model bacterium Bacillus subtilis has obtained a status as a robust workhorse for the production of various industrially relevant proteins and value added chemicals for multiple industries including agriculture, food and feed, biofuels, and pharmaceuticals. ${ }^{1}$

B. subtilis is particularly interesting as a cell factory due to its capacity to secrete large amounts of protein, which is far superior to that of most Gram-negative bacteria. Protein secretion occurs mainly through the signal peptide-dependent Sec and Tat pathways. ${ }^{2}$ Although extensively studied, rationally predicting signal peptide sequences leading to high secretion levels of a given protein is currently impossible, and current best practices consist of screening libraries of signal peptides. ${ }^{3-5}$ Additionally, parts such as promoters, ribosome binding sites (RBSs), genomic integration sites, etc. all influence final production titers, which highlights the importance of having a modular and customizable vector platform accompanied by a library of compatible and wellcharacterized parts. With the advancement of synthetic biology, the range of available molecular tools for B. subtilis has vastly increased, facilitating the engineering of the organism. $^{6-8}$ However, many tools used for expression in $B$. subtilis as well as other Gram-positive bacteria lack the modularity, customizability, and characterization of the tools available for Gram-negative bacteria.

One of the most widely used standards in prokaryotic synthetic biology is the Standard European Vector Architecture (SEVA) collection. ${ }^{9}$ However, a caveat of the SEVA standard is that it is only designed for construction of replicative vectors with a single origin of replication and a single resistance marker cassette. It is therefore not directly compatible with construction of shuttle vectors needed for many Gram-positive hosts. To accommodate this, an extension of the SEVA standard was recently developed for cloning shuttle vectors forB. subtilis, called the Bacillus SEVA sibling collection. ${ }^{10}$ This introduces a Golden Gate cloning ${ }^{11}$ step, which enables insertion of homology regions for subsequent genomic integration in B. subtilis while still remaining compatible with the SEVA standard. A drawback of this method is that the standard does not allow for the sole exchange of the Gram-positive antibiotic marker. Other alternative shuttle vector systems for Gram-positives have

Received: March 30, 2021

Published: November 18, 2021 


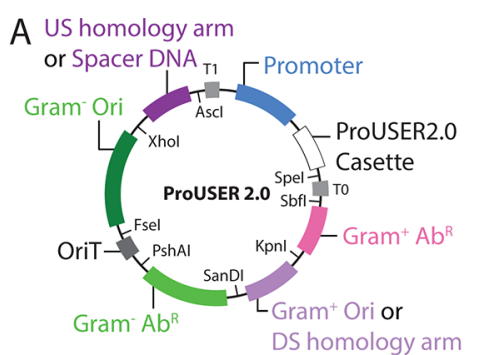

B
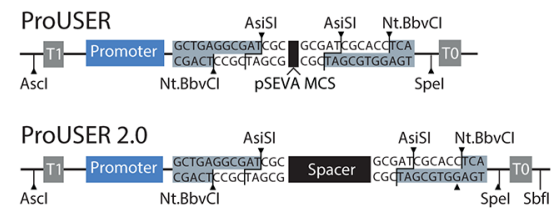

C

PrOUSER XXXXX

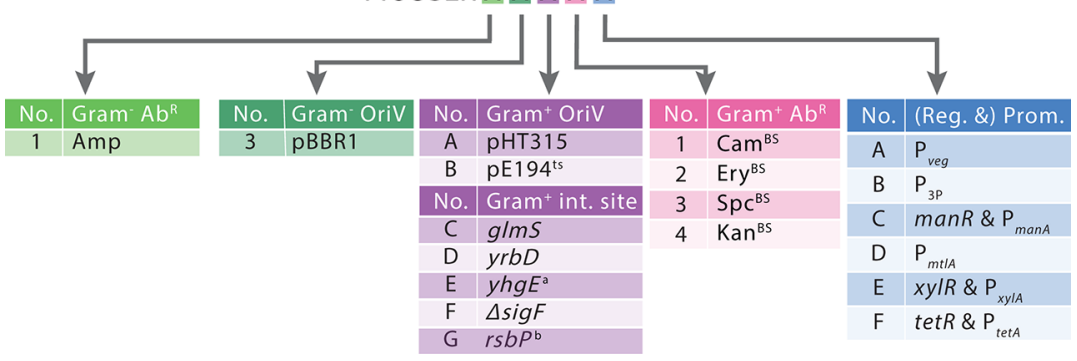

Figure 1. Schematic representation of the architecture of the ProUSER2.0 plasmid cassette. (A) Schematic representation of the modular structure of the ProUSER2.0 plasmids and the associated restriction sites. (B) Comparison of the original ProUSER cassette (top) and the ProUSER2.0 cassette (bottom). (C) Overview of the ProUSER2.0 nomenclature. The Gram-negative parts are numbered according to the SEVA nomenclature. Amp $=$ ampicillin, Cam $=$ chloramphenicol, Ery $=$ erythromycin, $\mathrm{Spc}=$ spectinomycin, Kan $=$ kanamycin, US $=$ upstream, DS $=$ downstream, $\mathrm{T} 0=$ $\rho$-independent transcriptional terminator of phage $\lambda$ (from pSEVA), T1 $=\rho$-independent transcriptional terminator of the $\operatorname{rrnB}$ operon of $E$. coli (from pSEVA). Superscript "BS" designates that the resistance marker is for B. subtilis. Superscript "a" designates that the sequence contains PshAI and SpeI restriction sites, and superscript "b" designates that the sequence contains an XhoI restriction site.

been developed, such as the pMTL80000 ${ }^{12}$ and the Bacillus BioBrick Box 2.0 $0^{13,14}$ collections. However, all of the mentioned standards are limited to a single plasmid modeeither replicative or integrative. Further, they all depend on cumbersome and often inadequate cloning techniques based on restriction enzymes for insertion of the cargo, particularly when multiple fragments are to be inserted. As a result, many shuttle vectors are built using PCR-based cloning approaches such as Gibson assembly ${ }^{15}$ or traditional USER cloning. ${ }^{16}$ This can lead to the accumulation of mutations in the plasmid backbone, which often remains undetected since these parts are typically not sequenced after assembly.

A variety of both constitutive and inducible promoters have been characterized for $B$. subtilis. This includes both native promoters such as $\mathrm{P}_{\text {mtlA }}{ }^{17} \mathrm{P}_{\text {manA }}{ }^{18}$ and $\mathrm{P}_{\text {veg }}{ }^{19}$ as well as heterologous and synthetic promoters such as $\mathrm{P}_{x y l A}{ }^{20} \mathrm{P}_{\text {tetA } A}{ }^{21}$ PspaS $^{22} \mathrm{PliaI},{ }^{23} \mathrm{P}_{\mathrm{BBa} \_} \mathrm{J}_{23101}{ }^{14}$ and $\mathrm{P}_{\text {amyL }}-\mathrm{P}_{\text {amy }}-\mathrm{P}_{\text {cryIIIA }}{ }^{-}$ cryIIIA $A_{\text {stab }}{ }^{24}$ (from hereon called $\mathrm{P}_{3 \mathrm{P}}$ ). The characterization of these promoters has predominantly been done using $\beta$ galactosidase reporter assays or by coupling the expression to a luminescence or fluorescence output using bulk culture measurements. These methods lack the power to resolve heterogeneity between individual cells in the population in contrast to the use of fluorescent proteins (FPs) in combination with flow cytometry techniques, which allows for identification of differences in outputs on the single-cell level. However, although flow cytometry constitutes a powerful method, the excitation wavelength of the most commonly used FP, green fluorescent protein (GFP), is associated with high background fluorescence from other molecules found in biological samples. ${ }^{25}$ This negatively affects the sensitivity of measurements and can result in difficulties detecting low fluorescence levels, associated with, for example, basal expression levels of tight inducible promoters. Bright red fluorescent proteins such as mRuby $2^{26}$ might therefore be better alternatives despite their relatively slow maturation time.

In this paper, we present a novel standard for assembly of shuttle vectors called ProUSER2.0. The standard allows for modular exchange of six elements, which can be tailored to the specific needs of a given application. The plasmid mode can be switched between integrative and replicative, allowing for increased freedom in the design. The standard is semicompatible with both the SEVA standard and the pMTL80000 standard and thus allows for the exchange of promoters and cargos from the existing standards to be incorporated into ProUSER2.0 vectors or vice versa. The promoters and novel integration sites characterized in this study are provided for easy use within the collection. The standard incorporates the previously reported ProUSER cloning approach, ${ }^{27}$ which allows different cargos to be easily inserted into the target vectors without the need for PCR amplification of the backbone. To highlight the ease with which constructs can be created with the ProUSER2.0 toolbox, we built and tested a signal peptide library to optimize the secretion of two industrially relevant proteins.

\section{RESULTS AND DISCUSSION}

ProUSER2.0 Vectors Allow for Easy and Standardized Assembly. To improve the synthetic biology toolbox for $B$. subtilis, we provide a well-characterized vector platform enabling the user to tailor the plasmids to their specific needs. To accommodate this, the plasmids were divided into seven modules: a Gram-negative resistance marker, a Grampositive resistance marker, a Gram-negative origin of replication (ori), an upstream homology arm or spacer sequence, a downstream homology arm or Gram-positive ori, an origin of transfer (oriT), and finally, the cargo site (Figure 1A). This design contains all of the modules needed to build 
Table 1. Overview of ProUSER2.0 Plasmids Deposited at Addgene ${ }^{a}$

\begin{tabular}{|c|c|c|c|c|c|}
\hline & $\mathrm{Gram}^{-} \mathrm{Ab}^{\mathrm{R}}$ & $\mathrm{Gram}^{-}$OriV & $\mathrm{Gram}^{+}$OriV or integration site & $\mathrm{Gram}^{+} \mathrm{Ab}^{\mathrm{R}}$ & regulator and promoter \\
\hline pProUSER13D2A & Amp & pBBR1 & $y r b D$ & Ery $^{\mathrm{BS}}$ & $\mathrm{P}_{V e g}$ \\
\hline pProUSER13C1B & Amp & pBBR1 & $g \operatorname{lm} S$ & $\mathrm{Cam}^{\mathrm{BS}}$ & $\mathrm{P}_{3 \mathrm{P}}$ \\
\hline pProUSER13F4C & Amp & pBBR1 & $\Delta \operatorname{sig} F$ & $\mathrm{Kan}^{\mathrm{BS}}$ & $\operatorname{manR}, \mathrm{P}_{\operatorname{man} A}$ \\
\hline pProUSER13B4D & Amp & pBBR1 & $\mathrm{pE} 194^{\mathrm{ts}}$ & $\mathrm{Kan}^{\mathrm{BS}}$ & $\mathrm{P}_{m t l A}$ \\
\hline pProUSER13A1E & Amp & pBBR1 & pHT315 & $\mathrm{Cam}^{\mathrm{BS}}$ & $x y l R, \mathrm{P}_{x y l A}$ \\
\hline pProUSER13E3F & Amp & pBBR1 & $y h g E$ & $\mathrm{Spc}^{\mathrm{BS}}$ & tetR, $\mathrm{P}_{\text {tetA }}$ \\
\hline pProUSER13G2F & Amp & pBBR1 & $r s b P$ & Ery $^{\mathrm{BS}}$ & tetR, $\mathrm{P}_{\text {tetA }}$ \\
\hline
\end{tabular}

${ }^{a} \mathrm{Amp}=$ ampicillin, Cam $=$ chloramphenicol, Ery = erythromycin, $\mathrm{Spc}=$ spectinomycin, Kan = kanamycin. Superscript "BS" designates that the resistance marker is for B. subtilis.

shuttle vectors for Gram-positive bacteria such as B. subtilis. The plasmid mode can be switched between integrative and replicative by replacing the homology arms with an ori (in place of the downstream homology arm) and a spacer sequence (in place of the upstream homology arm).

PCR amplification of a DNA molecule is prone to introducing errors in the DNA molecules despite the availability of high-fidelity enzymes. ${ }^{28}$ These errors can cause constructs to significantly deviate from the intended designs and cause unforeseen implications when implemented in the host strains. This is specifically problematic considering backbone parts are often not sequenced prior to further use.

The ProUSER2.0 standard circumvents this issue through the use of the nicking-based USER cloning approach called ProUSER $^{27}$ for making promoter-gene fusions in the cargo module. Here, a cloning cassette containing two AsiSI sites and two Nt.BbvCI sites is introduced downstream of the promoter. Digestion of the plasmids yields two overhangs compatible with USER cloning. The gene(s) of interest is PCR-amplified using complimentary USER overhangs and introduced into the vector by USER cloning. It was decided to update the ProUSER cassette by inserting a $\sim 1800$ bp spacer fragment (Figure 1B). This serves to make it easier to distinguish between the undigested and correctly digested plasmid in the cloning workflow. The ProUSER2.0 vectors were further designed so that the individual modules can be exchanged with modules of the same type by a simple restriction-ligation workflow. The plasmids are designed to be fully compatible with the application module of the pMTL80000 vector series and the oriT, the Gram-negative resistance marker, and the cargo site modules of the SEVA collection. This allows the user to utilize already existing parts from these collections or transfer the ProUSER2.0 cargo site to SEVA or pMTL80000 vectors if desired.

In order to easily translate plasmid names into meaningful concepts, a simple nomenclature was implemented. The nomenclature has a SEVA-style characteristic where numbers or letters represent the different modules, with new modules continuously being given the next available number or letter for the given module. For the sake of simplicity, parts shared with the SEVA collection were given the same numbers. An application-specific identifier is provided after the plasmid name (e.g., the gene being expressed). As an example, ProUSER13A1A-sfgf $p$ contains an ampicillin resistance marker for E. coli, the pBRR1 origin for E. coli, the pHT315 origin for B. subtilis, a chloramphenicol resistance marker for B. subtilis, and a cargo site containing the gene-encoding superfolder GFP under control of the $\mathrm{P}_{v e g}$ promoter. An overview of the naming concept and the modules currently available in the vector series is shown in Figure 1C, and ProUSER2.0 plasmids deposited at Addgene are listed in Table 1.

Red Fluorescent Proteins Are Good Reporters for $B$. subtilis when the Signal-to-Noise Ratio Is Critical. To assess small changes in expression levels as accurately as possible, reporter proteins with a high signal-to-noise ratio are required. Thus, in order to find a fluorescent protein (FP) with both a high signal-to-noise ratio as well as a strong signal, which would be able to support these measurements, the autofluorescent characteristics of $B$. subtilis were assessed by analyzing the emission spectra of exponential phase cultures at commonly used excitation wavelengths. The emission spectrum of the media was also measured, and the autofluorescence of the cells was calculated by correcting for the fluorescence of the media (Figure 2A). The data shows that $B$. subtilis is highly autofluorescent at shorter excitation wavelengths used for blue, cyan, green, and yellow FPs. In contrast, both the cells and the media were found to be almost devoid of autofluorescence at an excitation wavelength of 561 $\mathrm{nm}$, which is used for many red FPs (RFPs) ${ }^{29}$ as also found by Popp et al. ${ }^{13}$ This indicates that RFPs can be excellent choices as reporters for use in B. subtilis when the signal-to-noise ratio is a critical factor.

In order to find a suitable RFP forB. subtilis, the characteristics of mCherry, a codon-optimized version of mCherry (mCherryOPT), and mRuby 2 were assessed by expressing the genes under control of the constitutive promoter $\mathrm{P}_{v e g}$ integrated downstream of $\mathrm{glmS}$. The fluorescence intensities of the resulting strains were measured by flow cytometry in a time course experiment. Substantial heterogeneity was observed early in the cultivations, with the populations becoming homogeneous after $6 \mathrm{~h}$ (Figure S1). $\mathrm{P}_{\text {veg }}$ is highly active in B. subtilis during both the vegetative state and during the sporulation phase; however, mother cells have previously been shown to not express the veg gene. ${ }^{30}$ Thus, upon outgrowth from stationary phase overnight cultures, differences in cell states will result in heterogeneous expression levels but homogenizes when the entire culture reaches exponential phase expression.

We therefore chose the $6 \mathrm{~h}$ time point for comparison of the RFPs (Figure 2B). The strain expressing mCherryOPT exhibited an improved signal compared to mCherry; however, due to the superior signal strength of mRuby2, this was ultimately chosen as the RFP of choice. It should be noted that fluorescence settings can deviate slightly from the ideal optima for different FPs, which can influence the relative brightness.

A drawback of using mRuby2 is the relatively long maturation time $(150 \mathrm{~min})^{26}$ when compared to many blue, cyan, green, and yellow FPs, which have previously also been shown to be applicable for use inB. subtilis, ${ }^{13}$ with maturation 

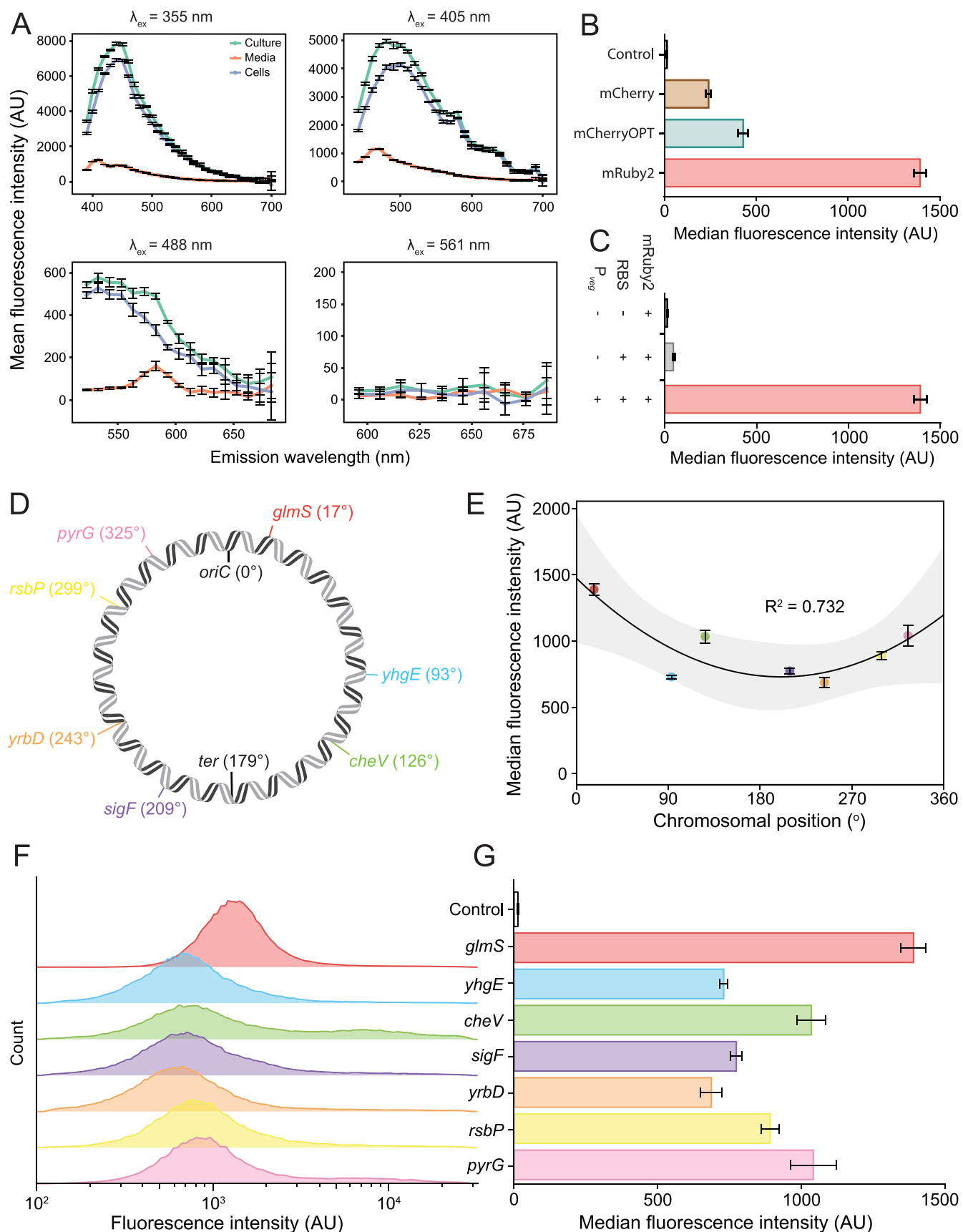

Figure 2. Characterization of RFPs and expression patterns at different integration sites. (A) Autofluorescence spectra ofB. subtilis at different excitation wavelengths. (B) Fluorescence intensities of strains expressing mCherry, mCherryOPT, and mRuby 2 from the $6 \mathrm{~h}$ samples, including a background strain control. (C) Analysis of the transcriptional isolation of the expression cassette. Fluorescence intensity of strains expressing mRuby2 with and without promoter and RBS, respectively. (D) Schematic representation of the position of the individual integration sites in the genome. (E) Fluorescence intensity as a function of chromosomal position of the integration sites. The line represents a second-order polynomial fitted to the values $\left(f(x)=0.0195 x^{2}-7.41 x+1473\right)$, and the gray area represents the $95 \%$ confidence intervals of the regression. (F) Population data from a representative sample of each strain expressing mRuby 2 from the different integration sites. $(G)$ Fluorescence intensities associated with the different integration sites. The bars/points indicate the means of the measured values, and the error bars indicate standard deviations of three biological replicates for the autofluorescence data and four biological replicates for all other data.

times as low as $15-40$ min. ${ }^{31}$ Thus, when a user wishes to identify fast temporal changes when a clear signal over noise is possible, other FPs can be better suited, highlighting the importance of selecting adequate FPs for the used system and desired output.

The isolation of the cargo site was also assessed by integrating a promoter-less RBS-mRuby 2 construct into the $g l m S$ locus and quantifying the fluorescence of this strain. This analysis showed that the cassette was sufficiently isolated to neglect the signal originating from unintentional transcription events (Figure 2C).

Characterizing Integration Sites Distributed throughout the Genome for the ProUSER2.0 Toolbox. To facilitate genomic expression, six novel neutral integration sites downstream of the genes $g l m S, y h g E, c h e V, y r b D, r s b P$, and pyrG as well as an integration site replacing the coding 

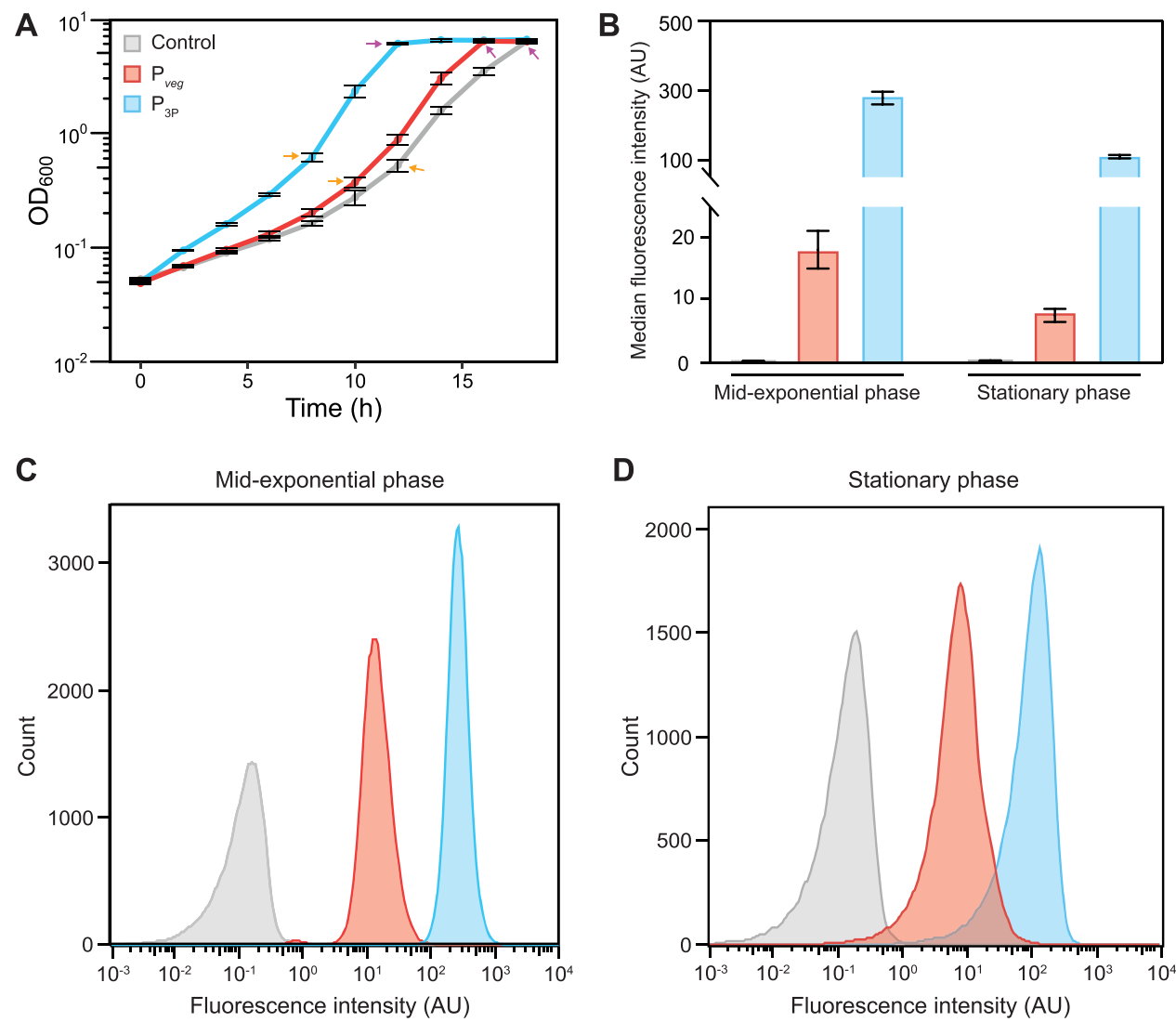

Figure 3. Comparison between $\mathrm{P}_{\text {veg }}$ and $\mathrm{P}_{3 \mathrm{P}}$. (A) Growth curves recorded during a time course experiment. The orange arrows indicate the exponential phase samples, and the purple arrows indicate the stationary phase samples. (B) Fluorescence intensities of the strains in exponential phase and stationary phase (logarithmic scale). The bars indicate the means of the measured values and the error bars indicate standard deviation of four biological replicates. (C) and (D) Population data for a representative replicate of each strain.

sequence of sigF were analyzed by expressing mRuby 2 under control of $\mathrm{P}_{\text {veg }}$ from these sites. The integration sites were chosen with the aim of reaching an even distribution throughout the genome (Figure 2D). Contrary to the most commonly used integration sites amyE, sacA, and $t h r C,{ }^{13}$ the novel $g l m S$, $y h g E$, cheV, $y r b D, r s b P$, and $p y r G$ integration sites are neutral, preventing the creation of a knockout or truncated version of the gene at the integration locus that may have unforeseen effects on cellular functions. The coding sequence of $\operatorname{sig} F$ was selected, since deletion of this gene results in a sporulation-deficient strain that can be desirable for industrial production. ${ }^{32}$ In an attempt to limit the risk of the integration event affecting the expression of the surrounding genes, the homology regions were designed to ensure that the integration cassette was integrated between two genes transcribed in opposite direction of the expression cassette. In line with this, there was no difference in the growth rates of strains harboring $\mathrm{P}_{\text {veg }}$-mRuby 2 expression cassettes in the different integration sites (Figure S2).

The fluorescence intensities of the resulting strains were monitored by flow cytometry in a time course experiment, and the $6 \mathrm{~h}$ data points were used for comparison. The data showed that the expression levels were dependent on chromosomal position, with the highest expression level observed close to oriC and the lowest around the ter region, in agreement with previous studies. ${ }^{10,33}$ The integration sites exhibited homogeneous populations, with the exception of cheV and pyrG, which both exhibited small subpopulations of high fluorescence, which could be due to some transcriptional readthrough in these loci (Figure $2 \mathrm{E}-\mathrm{G}$ ).

Characterizing Two Constitutive Promoters for the ProUSER Toolbox. Constitutive promoters are often used in B. subtilis for protein production and other applications where high expression is required and toxicity is not an issue. ${ }^{34}$ In order to provide parts for this, in addition to the frequently used $\mathrm{P}_{v e g}$ promoter, the $\mathrm{P}_{3 \mathrm{P}}$ promoter was characterized in $B$. subtilis by expressing mRuby 2 under its control. The $\mathrm{P}_{3 \mathrm{P}}$ promoter has previously been shown to facilitate production of heterologous proteins in large amounts. ${ }^{24,35}$ The expression from the $\mathrm{P}_{3 \mathrm{P}}$ promoter was compared to $\mathrm{P}_{v e g}$ in a time course experiment. Unexpectedly, the observed growth curves varied significantly between strains expressing mRuby 2 and the wildtype strain (Figure 3A). Repeating the experiment did not resolve this, and it was therefore concluded that this was caused by an unresolved biological effect rather than an experimental bias. Due to this shift, the flow cytometry measurements recorded in exponential phase and stationary phase for each strain were chosen for comparison (Figure 3B$\mathrm{D}$; the chosen data points are indicated by orange and purple arrows in Figure $3 \mathrm{~A}) . \mathrm{P}_{3 \mathrm{P}}$ was found to be significantly stronger than $\mathrm{P}_{\text {veg }}$ in both growth phases, increasing the fluorescence intensity about 42 -fold in the exponential phase and about 13fold in the stationary phase. This observed increase is probably due to the tandem promoter architecture of $\mathrm{P}_{3 \mathrm{P}}$, which has previously been shown to increase promoter strength, ${ }^{36}$ and it suggests that $\mathrm{P}_{3 \mathrm{P}}$ is a good choice for protein production, provided that the target protein is nontoxic to the production 

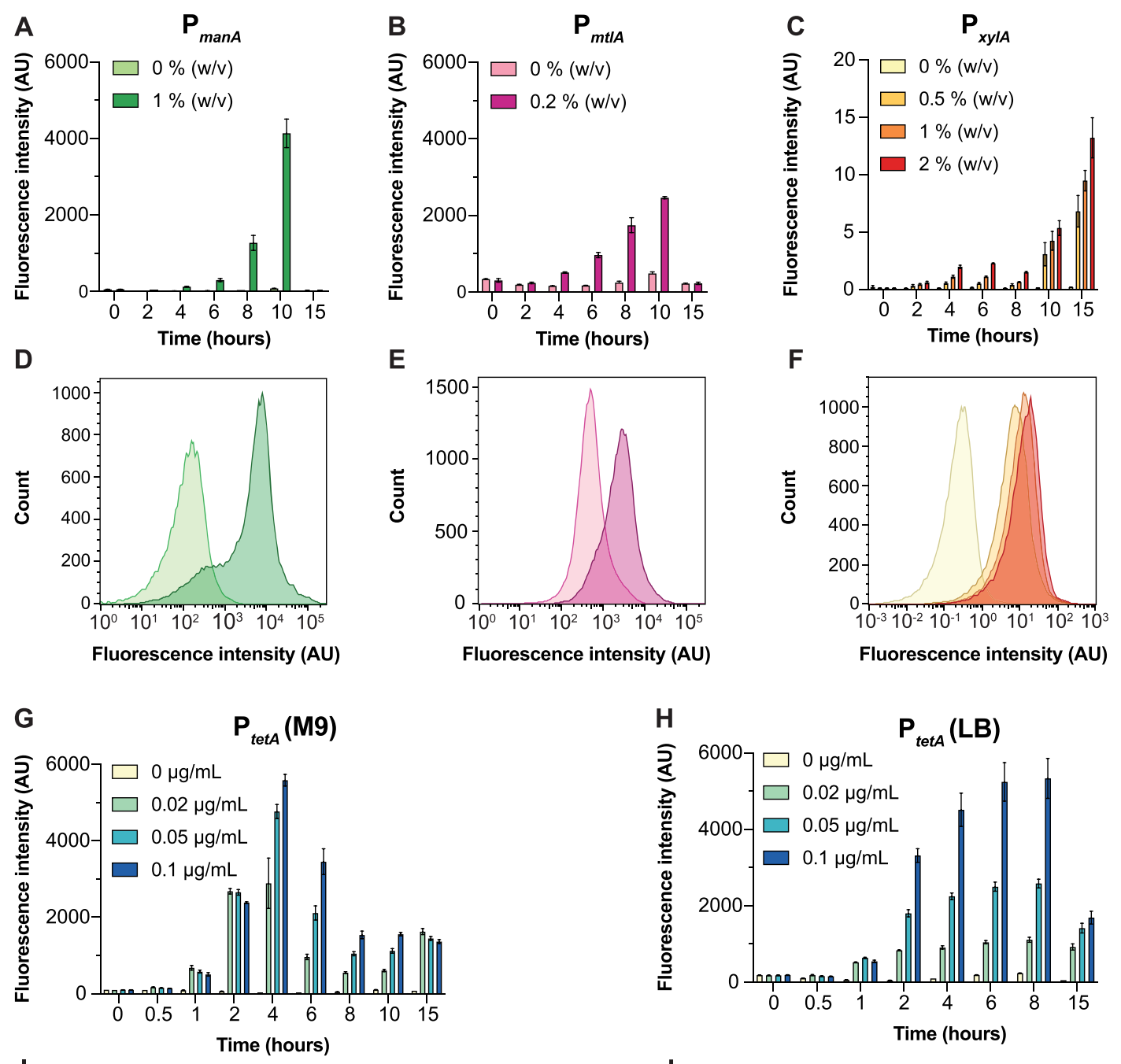

(1)

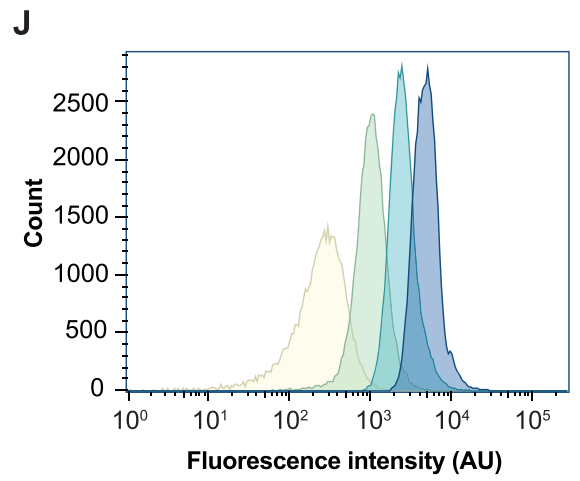

Figure 4. Comparison of inducible promoters with mRuby2 reporter. Median fluorescence intensities for each timepoint during the time course experiments for $\mathrm{P}_{\text {manA }}(\mathrm{A}), \mathrm{P}_{\text {mtlA }}(\mathrm{B}), \mathrm{P}_{x y l A}(\mathrm{C})$, and $\mathrm{P}_{\text {tetA }}$ in M9extra $(\mathrm{G})$ and $\mathrm{LB}(\mathrm{H})$, respectively. Corresponding population data from representative replicates of $\mathrm{P}_{\text {manA }}(\mathrm{D}), \mathrm{P}_{\text {mtlA }}(\mathrm{E}), \mathrm{P}_{x y l A}(\mathrm{~F})$, and $\mathrm{P}_{\text {tetA }}$ in M9extra (I) and LB (J), respectively. The population data is from the time point of highest fluorescence for each individual promoter $\left(t=10 \mathrm{~h}\right.$ for $\mathrm{P}_{\text {manA }}$ and $\mathrm{P}_{m t t A}, 15 \mathrm{~h}$ for $\mathrm{P}_{x y l A}, 4 \mathrm{~h}$ for $\mathrm{P}_{\text {tetA }}$ in M9extra, and $8 \mathrm{~h}$ for $\mathrm{P}_{\text {tetA }}$ in LB). Note that $\mathrm{P}_{x y l A}$ was characterized using a MACSQuant VYB cytometer, while the other promoters were characterized using a FACS Aria cytometer (for logistical reasons); thus, the absolute expression levels for $\mathrm{P}_{x y l A}$ cannot be compared with the other promoters in this figure. For comparison with sfGFP as reporter, see Figure S6. The bars indicate the means of the measured values, and the error bars are the standard deviation of four biological replicates.

host. None of the promoters resulted in the formation of fluorescent subpopulations at the chosen time points (Figure 3C,D).

Escherichia coli is often used as cloning strain when building constructs for B. subtilis. Leaky expression in a cloning strain can lead to mutations in the functional parts, especially if the expressed gene(s) introduces a stress condition. In order to simulate such unwanted expression in a routine cultivation step during cloning, the fluorescence of the $E$. coli cloning strains was also analyzed in overnight LB cultures (Figure S3). Here, $\mathrm{P}_{3 \mathrm{P}}$ was found to exhibit significantly reduced expression in $E$. coli compared to $\mathrm{P}_{v e g}$, rendering it a potentially better choice for cloning of genes that are toxic to the cloning strain. 
Characterizing Four Inducible Promoters for the ProUSER2.0 Toolbox. Inducible promoters are often used inB. subtilis for applications where timing of expression is important as well as when protein toxicity can hamper cell growth. Thus, in order to accommodate this in the ProUSER2.0 toolbox, four inducible promoters $-\mathrm{P}_{x y l A}, \mathrm{P}_{\text {manA }}$, $\mathrm{P}_{m t l A}$, and $\mathrm{P}_{t e t A}$-were characterized. Initially, we tested two versions of $\mathrm{P}_{m t l A}$; the wild-type $\mathrm{P}_{m+l A}$ (long) and a truncated $\mathrm{P}_{m t l A}$ version, which have previously been characterized. ${ }^{16} \mathrm{P}_{m t l A}$ (long) displayed lower expression levels than the truncated $\mathrm{P}_{\text {mtla }}$ version (Figure S4), and we therefore characterized only the latter thoroughly. The operational range of the promoters were first investigated in a time course experiment using a plate reader, where the strains were cultured and supplemented with inducers in a broad range of concentrations (Figure S5). Here, mRuby 2 was selected as the output of choice to adequately identify small changes in promoter activity over background levels as well as between different inducer concentrations. $\mathrm{P}_{\text {manA }}$ and $\mathrm{P}_{\text {mtl } A}$ exhibited binary on/off behavior, and it was therefore decided to perform the final characterization using two induction concentrations (no inducer and saturating concentration) for these promoters. In contrast, $\mathrm{P}_{x y l A}$ and $\mathrm{P}_{\text {tetA }}$ displayed titratable characteristics, and the final characterization of these promoters were therefore performed using four induction levels (no inducer, two intermediate concentrations, and saturating concentration). Anhydrotetracycline concentrations surpassing $0.1 \mu \mathrm{g} \mathrm{mL}{ }^{-1}$ were found to inhibit growth inB. subtilis (Figure S5), and this was therefore set as the maximum inducer concentration for $\mathrm{P}_{\text {tet } A}$.

$\mathrm{P}_{\text {manA }}, \mathrm{P}_{x y l A}$, and $\mathrm{P}_{\text {tetA }}$ were found to be highly repressed in the noninduced state, in contrast to $\mathrm{P}_{m t l A}$, which was found to be relatively leaky in the noninduced state (Figure S3). $\mathrm{P}_{\text {manA }}$ and $\mathrm{P}_{\text {tetA }}$ exhibited high expression levels in the induced state (Figure 4A,C,G), while $\mathrm{P}_{m t l A}$ had lower expression in the induced state than the other promoters (Figure 4B). The expression levels of $\mathrm{P}_{x y l A}$ were measured on a different flow cytometer, and the values from this experiment can therefore not be compared with those of the other promoters. The population data revealed that $\mathrm{P}_{\operatorname{man} A}$ showed some heterogeneities in the induced population (Figure $4 \mathrm{D}$ ). $\mathrm{P}_{x y l A}$ and $\mathrm{P}_{\text {tetA }}$ both exhibited a high degree of inducibility (Figure $4 \mathrm{C}-\mathrm{G}$ ).

To assess the time response of the inducible promoters, strains were constructed harboring the promoters controlling sfGFP $^{37}$ integrated into the glmS locus. Overall, these results show a similar yet approximate $2 \mathrm{~h}$ faster response upon induction when sfGFP is the reporter as compared to mRuby2, as would be expected by the respective maturation times of the proteins (Figure S6). $\mathrm{P}_{\text {manA }}$ and $\mathrm{P}_{m t l A(\text { short) }}$ show maximum fluorescence after $6 \mathrm{~h}$, whereas $\mathrm{P}_{x y l A}$ reaches maximum fluorescence intensity after $10 \mathrm{~h}$ and $\mathrm{P}_{\text {tetA }}$ only $2 \mathrm{~h}$ after induction. Notably, at $1 \mathrm{~h}$ post induction, $\mathrm{P}_{x y l A}$ and $\mathrm{P}_{\text {tetA }}$ show a fast response but with heterogeneous, nonexpressing subpopulations. This is resolved within the following hour and may be attributed to a combination of timed promoter response and maturation of the reporter protein. Interestingly, at $2 \mathrm{~h}$ post induction, $\mathrm{P}_{x y l A}$ expression levels drops somewhat, only to pick up again $10 \mathrm{~h}$ post induction (Figure S6). This behavior may be attributed to the growth on glucose, as also observed by the result of an endogenous catabolite repression when the cultures are grown and induced in the presence of glucose. Although the $\mathrm{P}_{x y l A}$ promoter, as used here, lacks the catabolite repressive element (CRE) binding site present in the beginning of $x y l A$, preventing repression by $\mathrm{CcpA}$ at this locus, a delayed response in promoter activity when grown on glucose as carbon source is still observed, which has been reported previously. ${ }^{14,38}$

Due to the desirable characteristics of $\mathrm{P}_{\text {tetA }}$ (low basal expression, high degree of titratability, high induced expression, and short induction time), the kinetics of the promoter was also assessed in LB media. Here, the kinetics were found to be similar to what was observed in M9extra, although with a more constant expression from 2 to $8 \mathrm{~h}$ in $\mathrm{LB}$ (Figure $4 \mathrm{H}-\mathrm{J}$ ). These findings suggest that $\mathrm{P}_{\text {tet } A}$ is a wellperforming inducible promoter useful for a range of conditions.

The leakiness of the inducibleB. subtilis promoters was furthermore compared in overnight LB cultures of $E$. coli (Figure S3). $\mathrm{P}_{\text {manA }}$ and $\mathrm{P}_{m t l A}$ exhibited intermediate basal expression levels in the cloning strain, while $\mathrm{P}_{x y l A}$ exhibited high basal expression in the cloning strain, despite exhibiting low basal expression in $B$. subtilis. In contrast, $\mathrm{P}_{\text {tetA }}$ was found to have exceptionally low basal expression in the cloning strain, which makes it an excellent choice for applications where this is critical in the cloning host.

The ProUSER2.0 Toolbox Accommodates Efficient Construction of Vector Libraries for Optimizing Secretion Levels. To demonstrate the applicability and ease of use of the ProUSER2.0 vectors and the toolbox, it was used to build vectors for production of two secreted proteins: the native $\alpha$-amylase from $B$. subtilis, AmyE, and the previously characterized lytic polysaccharide monooxygenase (LPMO) from Bacillus atrophaeus, BatLPMO10. AmyE was chosen since it constitutes a model protein for expression and secretion in $B$. subtilis, ${ }^{39}$ and the amount of secreted protein can easily be subjected to a functional assay in a semihigh-throughput manner. ${ }^{40}$ BatLPMO10 is a chitin-active LPMO that has previously been shown to express and secrete well in $B$. subtilis. ${ }^{35,41}$ Furthermore, since the choice of signal peptide is known to have a significant influence on the secretion efficiency of a given protein, ${ }^{3}$ both enzymes were screened with a library of 32 signal peptides (Table S4). The 32 signal peptides in the library were chosen based on previous secretomics data for $B$. subtilis. ${ }^{2,42,43}$ Using the ProUSER2.0 platform for the construction of signal peptide libraries has the advantage of a scarless $\mathrm{N}$ terminus of the target protein over classical restriction-ligation approaches. ${ }^{3}$ This can be critical for target proteins where the $\mathrm{N}$-terminal is crucial to the proper functioning of the produced protein, such as LPMOs. ${ }^{44}$ To further ease the cloning approach prior to generating the peptide libraries, all signal peptides were converted to having the signal peptide peptidase cleavage motif converted to ASA, providing a USER site for fusing the signal peptide to the protein of interest. In order to assure high expression, the genes and signal peptide-encoding sequences were cloned into the pProUSER13C1B (integrating in the high-expression integration site $g \operatorname{lm} S$ and with the strong constitutive promoter $\mathrm{P}_{3 \mathrm{P}}$ driving expression).

As expected, the amount of secreted protein was found to vary significantly between the signal peptides, with signal peptide $32\left(\mathrm{EgIS}^{\mathrm{SP}}\right)$ showing the highest extracellular amylase activity for the AmyE samples (Figure 5A, highlighted in dark purple) and signal peptide $31\left(\mathrm{CwlO}^{\mathrm{SP}}\right)$ resulting in the most intense band on the SDS-PAGE gel for BatLPMO10 (Figure $5 \mathrm{~B}$, highlighted in dark orange).

In agreement with other studies, ${ }^{4,5,45,46}$ the secretion patterns with a set of signal peptides are unique for individual proteins (Figure S7). This underlines why an optimization 


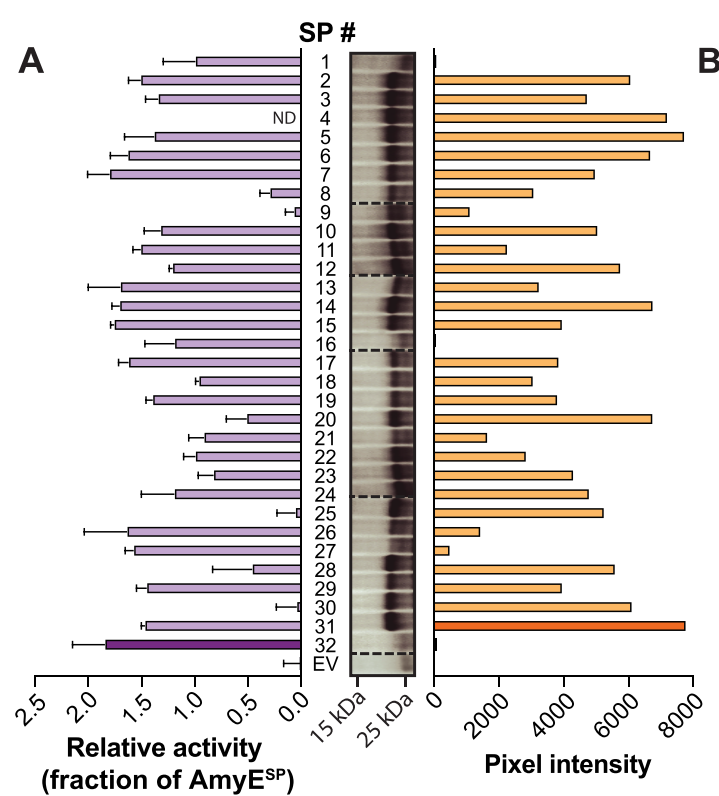

Figure 5. Screening signal peptide variants of AmyE and BatLPMO10. Secretion levels from signal peptide variants of (A) AmyE measured by amylase activity of culture supernatant normalized to the native signal peptide ( $\mathrm{AmyE}^{\mathrm{SP}}$ ) with the signal peptide yielding the highest activity $\left(32=\mathrm{EglS} S^{\mathrm{SP}}\right)$ highlighted in dark purple and $(\mathrm{B})$ BatLPMO10 titers measured by pixel intensities from the associated SDS-PAGE gel image with the signal peptide yielding the highest pixel intensity $\left(31=\mathrm{CwlO}^{\mathrm{SP}}\right)$ highlighted in dark orange. Cloning of the signal peptide $4\left(\mathrm{Epr}^{\mathrm{SP}}\right)$ was unsuccessful for AmyE; thus, no data (ND) was recorded. The activity data for AmyE are the means from three biological replicates, and the error bars are the standard deviation from these values. The titers for BatLPMO10 are measured values from single replicates. Detailed information for each signal peptide is available in Table S4.

approach, such as the one presented here, is relevant for optimizing production titers. Furthermore, this highlights the value of an efficient vector platform that is independent of PCR amplification of the backbone vector.

\section{CONCLUSIONS}

In this study, we combine the advantages of restrictionligation-based cloning with the flexibility of the USER-based ProUSER method in a highly customizable and easy-to-use vector platform forB. subtilis called the ProUSER2.0 toolbox. We established a workflow using mRuby 2 for characterizing genetic parts and thoroughly characterized seven novel integration sites and six promoters (two constitutive and four inducible). Last, we demonstrate the capacity of the developed toolbox by constructing expression vectors for AmyE and BatLPMO10 and optimizing their secretion using the ProUSER cloning method for generating signal peptide variants.

In order to facilitate the implementation of the ProUSER2.0 toolbox by the research community, seven vectors with selected parts will be made available through Addgene (Table 1). Adaptation of the ProUSER2.0 system within the community can allow simple further expansion of the current vector set when additional parts are desired, and we encourage everyone to contribute to the collection.

\section{MATERIALS AND METHODS}

Strains, Media, and Growth Conditions. Bacterial cells were routinely grown in LB media at $37{ }^{\circ} \mathrm{C}$ under shaking at 250 revolutions per minute (RPM) or on LB agar plates at 37 ${ }^{\circ} \mathrm{C}$ according to standard protocols. ${ }^{38,47}$ Cultures used for plasmid preparation were grown in media with double the amount of tryptone and yeast extract. When appropriate, media was supplemented with antibiotics $(100 \mu \mathrm{g} \mathrm{mL}$ ampicillin (Amp) for E. coli strains and $5 \mu \mathrm{g} \mathrm{mL} \mathrm{m}^{-1}$ chloramphenicol (Cam), $5 \mu \mathrm{g} \mathrm{mL}^{-1}$ kanamycin (Kan), $10 \mu \mathrm{g}$ $\mathrm{mL}^{-1}$ erythromycin (Ery), and $100 \mu \mathrm{g} \mathrm{mL}^{-1}$ spectinomycin (Spc) forB. subtilis strains). Characterization experiments were performed with a modified M9 medium called M9extra (12.8 g $\mathrm{L}^{-1} \mathrm{Na}_{2} \mathrm{HPO}_{4} \cdot 7 \mathrm{H}_{2} \mathrm{O}, 3 \mathrm{~g} \mathrm{~L}^{-1} \mathrm{KH}_{2} \mathrm{PO}_{4}, 0.5 \mathrm{~g} \mathrm{~L}^{-1} \mathrm{NaCl}, 1 \mathrm{~g} \mathrm{~L}^{-1}$ $\mathrm{NH}_{4} \mathrm{Cl}, 2 \mathrm{mM} \mathrm{MgSO}_{4}$, and $0.1 \mathrm{mM} \mathrm{CaCl} 2$ ) supplemented with $60 \mu \mathrm{M} \mathrm{FeCl}_{3}$, a trace element solution $\left(1.25 \mu \mathrm{M} \mathrm{MnCl}_{2}\right.$. $4 \mathrm{H}_{2} \mathrm{O}, 0.21 \mu \mathrm{M} \mathrm{CoCl}_{2} \cdot 6 \mathrm{H}_{2} \mathrm{O}, 0.85 \mu \mathrm{M} \mathrm{ZnSO}_{4} \cdot 7 \mathrm{H}_{2} \mathrm{O}, 0.05 \mu \mathrm{M}$ $\mathrm{CuCl}_{2} \cdot 2 \mathrm{H}_{2} \mathrm{O}, 0,08 \mu \mathrm{M} \mathrm{H}_{3} \mathrm{Bo}_{3}, 0.105 \mu \mathrm{M} \mathrm{NiCl} \cdot 6 \mathrm{H}_{2} \mathrm{O}, 0.125$ $\mu \mathrm{M} \mathrm{NaMoO}{ }_{4} \cdot 2 \mathrm{H}_{2} \mathrm{O}$, and $\left.0.3 \mu \mathrm{M} \mathrm{AlK}\left(\mathrm{SO}_{4}\right)_{2} \cdot 12 \mathrm{H}_{2} \mathrm{O}\right), 50 \mathrm{mg}$ $\mathrm{L}^{-1}$ L-tryptophan, and $10 \mathrm{~g} \mathrm{~L}^{-1}$ glucose as carbon source. Protein production were either performed in lysogeny broth (LB) media (LB broth (Lennox), Sigma-Aldrich, Saint Louis, MO, USA), or in Cal18-2 media ${ }^{48}\left(40 \mathrm{~g} \mathrm{~L}^{-1}\right.$ yeast extract, $1.3 \mathrm{~g}$ $\mathrm{L}^{-1} \mathrm{MgSO}_{4} \cdot 7 \mathrm{H}_{2} \mathrm{O}, 50 \mathrm{~g} \mathrm{~L}^{-1}$ maltodextrin (DE 13-17 (SigmaAldrich, Saint Louis, MO, USA)), $20 \mathrm{~g} \mathrm{~L}^{-1} \mathrm{NaH}_{2} \mathrm{PO}_{4} \cdot 2 \mathrm{H}_{2} \mathrm{O}$, $6.7 \mathrm{~mL} \mathrm{~L}^{-1} \mathrm{Na}_{2} \mathrm{MoO}_{4}$ stock solution $\left(2.0 \mathrm{~g} \mathrm{~L}^{-1}\right), 6.7 \mathrm{~mL} \mathrm{~L}^{-1}$ trace metal solution (consisting of $4.48 \mathrm{~g} \mathrm{~L}^{-1} \mathrm{MnSO}_{4} \cdot \mathrm{H}_{2} \mathrm{O}$, $3.33 \mathrm{~g} \mathrm{~L}^{-1} \mathrm{FeCl}_{3} \cdot 6 \mathrm{H}_{2} \mathrm{O}, 0.625 \mathrm{~g} \mathrm{~L}^{-1} \mathrm{CuSO}_{4} \cdot 5 \mathrm{H}_{2} \mathrm{O}$, and $7.12 \mathrm{~g}$ $\mathrm{L}^{-1} \mathrm{ZnSO}_{4} \cdot 7 \mathrm{H}_{2} \mathrm{O}$ ), and $100 \mu \mathrm{L} \mathrm{L}^{-1}$ Pluronic L-61 (SigmaAldrich, Saint Louis, MO, USA), adjusted to $\mathrm{pH}=6$ ).

PCR Amplification, DNA Purification, and Sequencing. PCR fragments for USER cloning were generated using Phusion U (Thermo Fisher Scientific, United States). Phusion HSII (Thermo Fisher Scientific, United States) was used for sequencing of genomic DNA fragments, and OneTaq (New England BioLabs, United States) was used for colony PCRs. Colony PCRs forE. coli strains were performed by suspending individual colonies in $20 \mu \mathrm{L}$ of LB media and adding $1 \mu \mathrm{L}$ of the suspended colonies as template in the reaction mixtures. Colony PCRs forB. subtilis strains were performed by suspending individual colonies in $20 \mu \mathrm{L}$ of LB media and diluting $10 \mu \mathrm{L}$ of the suspended colonies in $10 \mu \mathrm{L}$ of MilliQ water. Subsequently, the dilutions were stored on ice for $5 \mathrm{~min}$, followed by three cycles consisting of $1 \mathrm{~min}$ of heating in a microwave at $800 \mathrm{~W}$ and $30 \mathrm{~s}$ on ice. Afterward, the dilutions were again stored on ice for $5 \mathrm{~min}$, and $1 \mu \mathrm{L}$ of the microwaved dilutions were used as template in the reaction mixtures. PCR products were purified using a NucleoSpin PCR cleanup gel extraction kit (Macherey-Nagel, Germany), following the manufacturer's instructions. Plasmid DNA was purified fromE. coli cultures using a NucleoSpin Plasmid kit (Macherey-Nagel, Germany), following the manufacturer's instructions. Routine sequencing was performed using a Mix2Seq kit (Eurofins Genomics, Luxembourg), following the manufacturer's instructions.

Plasmid and Strains Construction. The ProUSER 2.0 vectors and initial plasmids used for characterization of the promoters, and integration sites were constructed using USER cloning or USER ligation PCR. USER reactions were performed by mixing the different fragments together with $1.2 \mu \mathrm{L}$ of $\mathrm{T} 4$ ligase buffer (New England BioLabs, United States), $1 \mu \mathrm{L}$ of USER enzyme (New England BioLabs, United 
States), and DNAse-/RNAse-free water to a total volume of 12 $\mu \mathrm{L}$. The reaction mixtures were incubated at $37^{\circ} \mathrm{C}$ for $25 \mathrm{~min}$ followed by another $25 \mathrm{~min}$ at $25{ }^{\circ} \mathrm{C}$. Subsequently, $8 \mu \mathrm{L}$ of MilliQ water was added to a total volume of $20 \mu \mathrm{L}$, and $5 \mu \mathrm{L}$ of the mix was used directly for transformation. For USER ligation PCRs, $0.8 \mu \mathrm{L}$ of T4 ligase buffer, $1 \mu \mathrm{L}$ of T4 ligase (New England BioLabs, United States), and $6.2 \mu \mathrm{L}$ of $\mathrm{MQ}$ water was added, and the mix was incubated at RT overnight. Two microliters of the mix was used as template for a PCR amplification; the fragment with the correct size was gelpurified and used directly for transformation inB. subtilis. For two ProUSER vectors, unwanted mutations occurring in the backbone were rescued through digestion and ligation, after which they were resequenced. mRuby2, sfGFP, and signal peptides were amplified with a consensus AGGAGG and a 7 bp spacer before the start codon. The replicative vectors pProUSER13A1A and pProUSER13B4A were validated by cloning mRuby 2 into the plasmids and confirming expression by fluorescence (data not shown). The temperature sensitivity of $\mathrm{pE} 194^{\text {ts }}$ was also verified as described in other studies. ${ }^{6}$ All strains, plasmids, and oligos used in this study are detailed in Tables S1-S3. The sequences of all plasmids used in this study are available in the Supporting Information.

ProUSER 2.0 Cloning. ProUSER 2.0 plasmids were digested by mixing $1 \mu \mathrm{g}$ of plasmid DNA with $1 \mu \mathrm{L}$ of AsiSI (New England BioLabs, United States), $5 \mu \mathrm{L}$ of CutSmart buffer, and DNAse-/RNAse-free water to a final volume of 50 $\mu \mathrm{L}$. The reactions were incubated at $37{ }^{\circ} \mathrm{C}$ for $16 \mathrm{~h}$ followed by inactivation at $80^{\circ} \mathrm{C}$ for $20 \mathrm{~min} .1 \mu \mathrm{L} \mathrm{Nt.BbvCI}$ was added to the reactions, which were subsequently incubated at $37{ }^{\circ} \mathrm{C}$ for $1 \mathrm{~h}$ followed by inactivation at $80{ }^{\circ} \mathrm{C}$ for $20 \mathrm{~min}$. The desired fragments containing 6 and 8 bp single-stranded DNA overhangs were selectively purified by elongated gel purification $(1 \mathrm{~h}, 100 \mathrm{kV})$. One to two microliters $(10-20$ ng) of the nicked ProUSER 2.0 plasmids were mixed with PCR-amplified cargos (mRuby2 or signal peptides and enzyme of interest) and subsequently USER-cloned as described above. To ease the workload prior to generating the signal peptide libraries, all signal peptides were converted to end on ASA (see Table S4), which enabled combining all signal peptides with a single enzyme-specific PCR reaction without modifying the $\mathrm{N}$ terminus of the enzymes.

Transformations of Bacterial Cells. E. coli transformations were performed as described previously. ${ }^{49} B$. subtilis 168 and PY79 and their derivatives were transformed with plasmid DNA by natural competence as described elsewhere $^{50}$ but without adding histidine to the SM1 and SM2 medium and at least $2 \mathrm{~h}$ of recovery. B. subtilis REG19 with mannose catabolism regenerated, and $B$. subtilis 168 glms::comKS was transformed with either plasmid DNA of USER-ligated PCR fragments as described elsewhere ${ }^{6}$ but with the recovery time extended to $2 \mathrm{~h}$.

Generation of Autofluorescence Spectra. An overnight culture was diluted to an $\mathrm{OD}_{600}$ of 0.1 in M9 media and grown in triplicates to an OD of 0.5. The cultures were dispensed in $200 \mu \mathrm{L}$ aliquots in a black Nunc 96-well plate (Thermo Fisher Scientific, United States), and autofluorescence was measured by performing emission spectra scans on a Synergy HM1 absorbance and fluorescence reader (BioTek Instruments, United States) with a gain value of 100 . All data points were measured from unique wells to avoid bleaching.

Integration Sites and Promoter Characterization Experiments. Single colonies were suspended in $1 \mathrm{~mL}$ of
LB and grown at $37{ }^{\circ} \mathrm{C}, 250 \mathrm{RPM}$ during the day. Ten microliters of culture was transferred to $50 \mathrm{~mL}$ of M9extra media supplemented with $0.02 \%(\mathrm{w} / \mathrm{v})$ yeast extract, $10 \mathrm{~g} \mathrm{~L}^{-1}$ glucose, $50 \mathrm{mg} \mathrm{L}^{-1} \mathrm{~L}$-tryptophan, and appropriate antibiotics in $250 \mathrm{~mL}$ Erlenmeyer flasks and grown overnight at $37^{\circ} \mathrm{C}, 250$ RPM. Overnight cultures were diluted in $50 \mathrm{~mL}$ of M9extra media supplemented with $10 \mathrm{~g} \mathrm{~L}^{-1}$ glucose and $50 \mathrm{mg} \mathrm{L}^{-1} \mathrm{~L}-$ tryptophan to an $\mathrm{OD}_{600}$ of 0.05 or 0.1 and grown at $37^{\circ} \mathrm{C}, 250$ RPM in $250 \mathrm{~mL}$ Erlenmeyer shake flasks in duplicates for initial experiments and quadruplicates for final experiments. Strains with inducible promoters were grown up to an $\mathrm{OD}_{600}$ of $0.1-0.2$ before induction.

Sample Preparation for Flow Cytometry. Cells were fixed by centrifuging $1 \mathrm{~mL}$ of culture at $6000 \mathrm{~g}$ for $10 \mathrm{~min}$, removing the supernatant, and resuspending the pellet in 500 $\mu \mathrm{L}$ of $2 \%$ paraformaldehyde in phosphate-buffered saline (PBS) (Thermo Fisher Scientific, United States). The samples were left at room temperature for $30 \mathrm{~min}$ to $2 \mathrm{~h}$. Subsequently, the centrifugation step was repeated, the supernatant was removed, and the pellet was resuspended in $500 \mu \mathrm{L}$ of PBS. The fixed cells were stored at $4{ }^{\circ} \mathrm{C}$ until analysis and analyzed within 2 weeks of sampling.

Quantification of Fluorescence. The fluorescence of the fixed cells in the initial induction experiments were analyzed using a Synergy HM1 absorbance and fluorescence reader (BioTek Instruments, United States). The samples were dispensed in a black Nunc 96-well plate (Thermo Fisher Scientific, United States) in $200 \mu \mathrm{L}$ aliquots and measured using excitation and emission values of 561 and $610 \mathrm{~nm}$, respectively, and a gain value of 150 . The fluorescence of the cells in the final characterization of the integration sites and inducible promoters were performed by flow cytometry using a FACS Aria cytometer (BD Bioscience, USA) or a MACSQuant VYB cytometer (Miltenyi Biotec, Germany). The fluorescence of single cells was measured after appropriate gating in the forward scatter and side scatter channels. For the FACS Aria cytometer, samples were analyzed by making appropriate dilutions in FACS Flow. Fluorescence was detected by excitation with a $561 \mathrm{~nm}$ laser, using a 610/20 nm band-pass and $600 \mathrm{~nm}$ long-pass filter set. A total of 50,000 events were recorded using the following voltage settings: forward scatter, $236 \mathrm{~V}$; side scatter, $283 \mathrm{~V}$; PE-Texas Red, $700 \mathrm{~V}$. For the MACSQuant VYB cytometer, the samples were run directly on the cytometer. mRuby2 fluorescence was measured by excitation with a $561 \mathrm{~nm}$ laser using a 615/20 nm band-pass filter, whereas sfGFP fluorescence was measured by excitation with a $488 \mathrm{~nm}$ laser and a $525 / 50 \mathrm{~nm}$ band-pass filter. Up to 50,000 events were recorded from the $200 \mu \mathrm{L}$ sample using the following voltage settings: forward scatter, $450 \mathrm{~V}$; side scatter, $425 \mathrm{~V}$; Y2 Channel, 496 V for leakiness measurements; $399 \mathrm{~V}$ for all other measurements; and B1 channel, $500 \mathrm{~V}$. Data was analyzed using FlowJo (Tree Star Inc., Asland, OR). All fluorescence data reported are the numerical pulse areas.

AmyE and BatLPM010 Production. A single colony of the desired strain was inoculated in either $600 \mu \mathrm{L}$ of LB in a 96-well plate or $3 \mathrm{~mL}$ of LB in a 24-well plate supplemented with appropriate antibiotics. The culture was grown $\mathrm{O} / \mathrm{N}$ at 37 ${ }^{\circ} \mathrm{C}$ with $250 \mathrm{RPM}$ shaking and back-diluted to 1:300 in either $300 \mu \mathrm{L}$ of fresh LB in a 96-well plate (AmyE samples) or $3 \mathrm{~mL}$ of fresh Cal18-2 media in a 24-well plate (BatLPMO10 samples). In both cases, the media was supplemented with appropriate antibiotics. LB cultures were grown for $16 \mathrm{~h}$ at 37 ${ }^{\circ} \mathrm{C}$ with $250 \mathrm{RPM}$ shaking, while Cal18-2 cultures were grown 
for $72 \mathrm{~h}$ at $20{ }^{\circ} \mathrm{C}$ with $250 \mathrm{RPM}$ shaking. The cells were harvested by centrifugation at $6000 \mathrm{~g}$ for $5 \mathrm{~min}$ at $4{ }^{\circ} \mathrm{C}$, the pellet was discarded, and the supernatant was used for further analysis.

Amylase Activity Assay. The assay was adapted from Xiao et al. ${ }^{40}$ The supernatants were diluted five times in PBS,

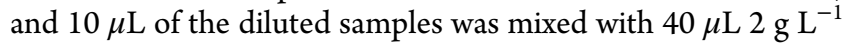
starch in $100 \mathrm{mM}$ phosphate buffer $(\mathrm{pH}=5.9)$ solution. The reaction mixtures were incubated at $65{ }^{\circ} \mathrm{C}$ for $25 \mathrm{~min}$, and the reactions were stopped by adding $50 \mu \mathrm{L}$ of $1 \mathrm{M} \mathrm{HCl}$. The reactions were mixed 1:1 with an iodine solution consisting of $5 \mathrm{mM} \mathrm{I}_{2}$ and $50 \mathrm{mM} \mathrm{KI}$. The background was measured by substituting the sample with PBS. The absorbance values were measured at $580 \mathrm{~nm}$, and the relative activity units were calculated as $U=\left(\mathrm{Abs}_{580, \text { background }}-\mathrm{Abs}_{580, \text { sample }}\right) / \mathrm{Abs}_{580, \mathrm{AmyE}} \mathrm{SP}$.

SDS-PAGE Analysis. Samples were mixed 1:1 with sample buffer ( $8 \mathrm{M}$ urea, $0.0105 \%(\mathrm{w} / \mathrm{v})$ bromophenol blue, $5 \mathrm{mM}$ EDTA, $100 \mathrm{mM}$ Tris- $\mathrm{HCl} \mathrm{pH} 6.8,4 \%$ (w/v) SDS, and 25\% (v/v) glycerol), and heated to $98{ }^{\circ} \mathrm{C}$ for $10 \mathrm{~min}$. Ten microliters of the sample was loaded on a 4-20\% MiniPROTEAN-TGX gel (BioRad, Hercules, CA, USA) and run for $160 \mathrm{~V}$ for $50 \mathrm{~min}$. Gels were stained for at least $4 \mathrm{~h}$ using InstantBlue Protein Stain (Expedeon Inc., San Diego, CA, USA) and destained $\mathrm{O} / \mathrm{N}$ using demineralized water. Pixel values were calculated using Fiji software. ${ }^{51}$

\section{ASSOCIATED CONTENT}

\section{SI Supporting Information}

The Supporting Information is available free of charge at https://pubs.acs.org/doi/10.1021/acssynbio.1c00130.

(Figure S1) Population data for mCherry, mCherryOPT and mRuby 2 expressed from $\mathrm{P}_{\text {veg }}$ over time; (Figure S2) growth rates of $B$. subtilis strain integration sites; (Figure S3) leakiness data for the promoters characterized in this study; (Figure S4) comparison between the two versions of PmtlA; (Figure S5) initial inducer concentration screening of the promoters; (Figure S6) comparison of inducible promoters with sfGFP as reporter; (Figure S7) correlation between the secretion of AmyE and BatLPMO10 for different signal peptides; (Tables S1S3) strains, plasmids, and oligos used in this study; (Table S4) information about the signal peptides in the signal peptide library (PDF)

GenBank files of plasmids (ZIP)

\section{AUTHOR INFORMATION}

\section{Corresponding Author}

Sheila Ingemann Jensen - The Novo Nordisk Foundation Center for Biosustainability, Technical University of Denmark, Kongens Lyngby 2800, Denmark; 이이.org/ 0000-0001-8277-5907; Email: shin@biosustain.dtu.dk

\section{Authors}

Kristoffer Bach Falkenberg - The Novo Nordisk Foundation Center for Biosustainability, Technical University of Denmark, Kongens Lyngby 2800, Denmark

Viviënne Mol - The Novo Nordisk Foundation Center for Biosustainability, Technical University of Denmark, Kongens Lyngby 2800, Denmark

Arrate Sainz de la Maza Larrea - The Novo Nordisk Foundation Center for Biosustainability, Technical University of Denmark, Kongens Lyngby 2800, Denmark
Ivan Pogrebnyakov - The Novo Nordisk Foundation Center for Biosustainability, Technical University of Denmark, Kongens Lyngby 2800, Denmark

Morten H. H. Nørholm - The Novo Nordisk Foundation Center for Biosustainability, Technical University of Denmark, Kongens Lyngby 2800, Denmark; ㅇoㄷ․org/ 0000-0002-7871-5191

Alex Toftgaard Nielsen - The Novo Nordisk Foundation Center for Biosustainability, Technical University of Denmark, Kongens Lyngby 2800, Denmark

Complete contact information is available at:

https://pubs.acs.org/10.1021/acssynbio.1c00130

\section{Author Contributions}

${ }^{\dagger}$ K.B.F. and V.M. contributed equally to this work

\section{Author Contributions}

K.B.F., V.M., and S.I.J. conceived the study and designed the experiments. K.B.F., V.M., A.S.d.l.M.L., and I.P. performed the experiments. K.B.F., V.M., and S.I.J. analyzed the data. K.B.F., V.M., and S.I.J. wrote the manuscript. All authors have read, corrected, and approved the manuscript.

\section{Notes}

The authors declare no competing financial interest.

\section{ACKNOWLEDGMENTS}

This study was funded by the Independent Research Foundation Denmark (grant no. 7017-00321B (S.I.J.)). We further acknowledge funding from the Novo Nordisk Foundation (grant nos. NNF18CC0033664 (V.M.) and NNF20CC0035580).

\section{REFERENCES}

(1) Su, Y.; Liu, C.; Fang, H.; Zhang, D. Bacillus subtilis: a universal cell factory for industry, agriculture, biomaterials and medicine. Microb. Cell Fact. 2020, 19, 173.

(2) Tjalsma, H.; Antelmann, H.; Jongbloed, J. D. H.; Braun, P. G.; Darmon, E.; Dorenbos, R.; Dubois, J.-Y. F.; Westers, H.; Zanen, G.; Quax, W. J.; Kuipers, O. P.; Bron, S.; Hecker, M.; van Dijl, J. M. Proteomics of protein secretion by Bacillus subtilis: separating the "secrets" of the secretome. Microbiol. Mol. Biol. Rev. 2004, 68, 207233.

(3) Brockmeier, U.; Caspers, M.; Freudl, R.; Jockwer, A.; Noll, T.; Eggert, T. Systematic screening of all signal peptides from Bacillus subtilis: a powerful strategy in optimizing heterologous protein secretion in Gram-positive bacteria. J. Mol. Biol. 2006, 362, 393-402.

(4) Degering, C.; Eggert, T.; Puls, M.; Bongaerts, J.; Evers, S.; Maurer, K. H.; Jaeger, K. E. Optimization of protease secretion in Bacillus subtilis and Bacillus licheniformis by screening of homologous and heterologous signal peptides. Appl. Environ. Microbiol. 2010, 76, 6370-6376.

(5) Knapp, A.; Ripphahn, M.; Volkenborn, K.; Skoczinski, P.; Jaeger, K. E. Activity-independent screening of secreted proteins using split GFP. J. Biotechnol. 2017, 258, 110-116.

(6) Altenbuchner, J. Editing of the Bacillus subtilis Genome by the CRISPR-Cas9 System. Appl. Environ. Microbiol. 2016, 82, 54215427.

(7) Peters, J. M.; Colavin, A.; Shi, H.; Czarny, T. L.; Larson, M. H.; Wong, S.; Hawkins, J. S.; Lu, C. H. S.; Koo, B. M.; Marta, E.; Shiver, A. L.; Whitehead, E. H.; Weissman, J. S.; Brown, E. D.; Qi, L. S.; Huang, K. C.; Gross, C. A. A Comprehensive, CRISPR-based Functional Analysis of Essential Genes in Bacteria. Cell 2016, 165, $1493-1506$.

(8) Rahmer, R.; Morabbi Heravi, K.; Altenbuchner, J. Construction of a Super-Competent Bacillus subtilis 168 Using the PmtlA -comKS Inducible Cassette. Front. Microbiol. 2015, 6, 1431. 
(9) Silva-Rocha, R.; Martinez-Garcia, E.; Calles, B.; Chavarria, M.; Arce-Rodriguez, A.; de Las Heras, A.; Paez-Espino, A. D.; DuranteRodriguez, G.; Kim, J.; Nikel, P. I.; Platero, R.; de Lorenzo, V. The Standard European Vector Architecture (SEVA): a coherent platform for the analysis and deployment of complex prokaryotic phenotypes. Nucleic Acids Res. 2013, 41, D666-D675.

(10) Radeck, J.; Meyer, D.; Lautenschläger, N.; Mascher, T. Bacillus SEVA siblings: A Golden Gate-based toolbox to create personalized integrative vectors for Bacillus subtilis. Sci. Rep. 2017, 7, 14134.

(11) Engler, C.; Kandzia, R.; Marillonnet, S. A one pot, one step, precision cloning method with high throughput capability. PLoS One 2008, 3, e3647.

(12) Heap, J. T.; Pennington, O. J.; Cartman, S. T.; Minton, N. P. A modular system for Clostridium shuttle plasmids. J. Microbiol. Methods 2009, 78, 79-85.

(13) Popp, P. F.; Dotzler, M.; Radeck, J.; Bartels, J.; Mascher, T. The Bacillus BioBrick Box 2.0: expanding the genetic toolbox for the standardized work with Bacillus subtilis. Sci. Rep. 2017, 7, 15058.

(14) Radeck, J.; Kraft, K.; Bartels, J.; Cikovic, T.; Durr, F.; Emenegger, J.; Kelterborn, S.; Sauer, C.; Fritz, G.; Gebhard, S.; Mascher, T. The Bacillus BioBrick Box: generation and evaluation of essential genetic building blocks for standardized work with Bacillus subtilis. J. Biol. Eng. 2013, 7, 29.

(15) Gibson, D. G.; Young, L.; Chuang, R.-Y.; Venter, J. C.; Hutchison, C. A., III; Smith, H. O. Enzymatic assembly of DNA molecules up to several hundred kilobases. Nat. Methods 2009, 6, 343-345.

(16) Nour-Eldin, H. H.; Hansen, B. G.; Nørholm, M. H.; Jensen, J. K.; Halkier, B. A. Advancing uracil-excision based cloning towards an ideal technique for cloning PCR fragments. Nucleic Acids Res. 2006, 34 , e122.

(17) Heravi, K. M.; Wenzel, M.; Altenbuchner, J. Regulation of mtl operon promoter of Bacillus subtilis: requirements of its use in expression vectors. Microb. Cell Fact. 2011, 10, 83.

(18) Wenzel, M.; Muller, A.; Siemann-Herzberg, M.; Altenbuchner, J. Self-inducible Bacillus subtilis expression system for reliable and inexpensive protein production by high-cell-density fermentation. Appl. Environ. Microbiol. 2011, 77, 6419-6425.

(19) Le Grice, S. F. J.; Shih, C.-C.; Whipple, F.; Sonenshein, A. L. Separation and analysis of the RNA polymerase binding sites of a complex Bacillus subtilis promoter. Mol. Gen. Genet. 1986, 204, 229236.

(20) Rygus, T.; Hillen, W. Inducible high-level expression of heterologous genes in Bacillus megaterium using the regulatory elements of the xylose-utilization operon. Appl. Microbiol. Biotechnol. 1991, 35, 594-599.

(21) Kamionka, A.; Bertram, R.; Hillen, W. Tetracycline-dependent conditional gene knockout in Bacillus subtilis. Appl. Environ. Microbiol. 2005, 71, 728-733.

(22) Bongers, R. S.; Veening, J. W.; Van Wieringen, M.; Kuipers, O. P.; Kleerebezem, M. Development and characterization of a subtilinregulated expression system in Bacillus subtilis: strict control of gene expression by addition of subtilin. Appl. Environ. Microbiol. 2005, 71, $8818-8824$.

(23) Mascher, T.; Zimmer, S. L.; Smith, T. A.; Helmann, J. D. Antibiotic-inducible promoter regulated by the cell envelope stresssensing two-component system LiaRS of Bacillus subtilis. Antimicrob. Agents Chemother. 2004, 48, 2888-2896.

(24) Jensen, K.; Østergaard, P. R.; Wilting, R.; Lassen, S. F. Identification and characterization of a bacterial glutamic peptidase. BMC Biochem. 2010, 11, 47.

(25) Kremers, G. J.; Gilbert, S. G.; Cranfill, P. J.; Davidson, M. W.; Piston, D. W. Fluorescent proteins at a glance. J. Cell Sci. 2011, 124, $157-160$.

(26) Lam, A. J.; St-Pierre, F.; Gong, Y.; Marshall, J. D.; Cranfill, P. J.; Baird, M. A.; McKeown, M. R.; Wiedenmann, J.; Davidson, M. W.; Schnitzer, M. J.; Tsien, R. Y.; Lin, M. Z. Improving FRET dynamic range with bright green and red fluorescent proteins. Nat. Methods 2012, 9, 1005-1012.
(27) Calero, P.; Jensen, S. I.; Nielsen, A. T. Broad-Host-Range ProUSER Vectors Enable Fast Characterization of Inducible Promoters and Optimization of $p$-Coumaric Acid Production in Pseudomonas putida KT2440. ACS Synth. Biol. 2016, 5, 741-753.

(28) Potapov, V.; Ong, J. L. Examining Sources of Error in PCR by Single-Molecule Sequencing. PLoS One 2017, 12, e0169774.

(29) Lambert, T. J. FPbase: a community-editable fluorescent protein database. Nat. Methods 2019, 16, 277-278.

(30) Fukushima, T.; Ishikawa, S.; Yamamoto, H.; Ogasawara, N.; Sekiguchi, J. Transcriptional, functional and cytochemical analyses of the veg gene in Bacillus subtilis. J. Biochem. 2003, 133, 475-483.

(31) Balleza, E.; Kim, J. M.; Cluzel, P. Systematic characterization of maturation time of fluorescent proteins in living cells. Nat. Methods 2018, 15, 47-51.

(32) Overkamp, W.; Kuipers, O. P. Transcriptional Profile of Bacillus subtilis sigF-Mutant during Vegetative Growth. PLoS One 2015, 10, e0141553.

(33) Sauer, C.; Syvertsson, S.; Bohorquez, L. C.; Cruz, R.; Harwood, C. R.; van Rij, T.; Hamoen, L. W. Effect of Genome Position on Heterologous Gene Expression in Bacillus subtilis: An Unbiased Analysis. ACS Synth. Biol. 2016, 5, 942-947.

(34) Song, Y.; Nikoloff, J. M.; Fu, G.; Chen, J.; Li, Q.; Xie, N.; Zheng, P.; Sun, J.; Zhang, D. Promoter Screening from Bacillus subtilis in Various Conditions Hunting for Synthetic Biology and Industrial Applications. PLoS One 2016, 11, e0158447.

(35) Hernández-Rollán, C.; Falkenberg, K. B.; Rennig, M.; Bertelsen, A. B.; Ipsen, J. O.; Brander, S.; Daley, D. O.; Johansen, K. S.; Nørholm, M. H. H. LyGo: A Platform for Rapid Screening of Lytic Polysaccharide Monooxygenase Production. ACS Synth. Biol. 2021, 10, 897-906.

(36) Liu, D.; Mao, Z.; Guo, J.; Wei, L.; Ma, H.; Tang, Y.; Chen, T.; Wang, Z.; Zhao, X. Construction, Model-Based Analysis, and Characterization of a Promoter Library for Fine-Tuned Gene Expression in Bacillus subtilis. ACS Synth. Biol. 2018, 7, 1785-1797.

(37) Pédelacq, J.-D.; Cabantous, S.; Tran, T.; Terwilliger, T. C.; Waldo, G. S. Engineering and characterization of a superfolder green fluorescent protein. Nat. Biotechnol. 2006, 24, 79-88.

(38) Dahl, M. K.; Schmiedel, D.; Hillen, W. Glucose and glucose-6phosphate interaction with Xyl repressor proteins from Bacillus spp. may contribute to regulation of xylose utilization. J. Bacteriol. 1995, $177,5467-5472$.

(39) Liu, Y.; Lu, F.; Chen, G.; Snyder, C. L.; Sun, J.; Li, Y.; Wang, J.; Xiao, J. High-level expression, purification and characterization of a recombinant medium-temperature alpha-amylase from Bacillus subtilis. Biotechnol. Lett. 2010, 32, 119-124.

(40) Xiao, Z.; Storms, R.; Tsang, A. A quantitative starch-iodine method for measuring alpha-amylase and glucoamylase activities. Anal. Biochem. 2006, 351, 146-148.

(41) Yu, M.-J.; Yoon, S.-H.; Kim, Y.-W. Overproduction and characterization of a lytic polysaccharide monooxygenase in Bacillus subtilis using an assay based on ascorbate consumption. Enzyme Microb. Technol. 2016, 93-94, 150-156.

(42) Antelmann, H.; Tjalsma, H.; Voigt, B.; Ohlmeier, S.; Bron, S.; van Dijl, J. M.; Hecker, M. A proteomic view on genome-based signal peptide predictions. Genome Res. 2001, 11, 1484-1502.

(43) Tjalsma, H.; Bolhuis, A.; Jongbloed, J. D.; Bron, S.; van Dijl, J. M. Signal peptide-dependent protein transport in Bacillus subtilis: a genome-based survey of the secretome. Mol. Gen. Genet. 2000, 64, 515-547.

(44) Gaber, Y.; Rashad, B.; Hussein, R.; Abdelgawad, M.; Ali, N. S.; Dishisha, T.; Várnai, A. Heterologous expression of lytic polysaccharide monooxygenases (LPMOs). Biotechnol. Adv. 2020, 43, 107583.

(45) Fu, G.; Liu, J.; Li, J.; Zhu, B.; Zhang, D. Systematic Screening of Optimal Signal Peptides for Secretory Production of Heterologous Proteins in Bacillus subtilis. J. Agric. Food Chem. 2018, 66, 1314113151.

(46) Yao, D.; Su, L.; Li, N.; Wu, J. Enhanced extracellular expression of Bacillus stearothermophilus $\alpha$-amylase in Bacillus subtilis through 
signal peptide optimization, chaperone overexpression and $\alpha$-amylase mutant selection. Microb. Cell Fact. 2019, 18, 69.

(47) Sambrook, J.; Russell, D. W. Molecular cloning: a laboratory manual; 3rd Ed.; Cold Spring Harbor Laboratory Press; New York, 2001.

(48) Rasmussen, M. D.; Bjoernvad, M. E.; Diers, I. Patent No. WO 00/75344, World Intellectual Property Organization, 2000

(49) Inoue, H.; Nojima, H.; Okayama, H. High efficiency transformation of Escherichia coli with plasmids. Gene 1990, 96, 2328.

(50) Vojcic, L.; Despotovic, D.; Martinez, R.; Maurer, K. H.; Schwaneberg, U. An efficient transformation method for Bacillus subtilis DB104. Appl. Microbiol. Biotechnol. 2012, 94, 487-493.

(51) Schindelin, J.; Arganda-Carreras, I.; Frise, E.; Kaynig, V.; Longair, M.; Pietzsch, T.; Preibisch, S.; Rueden, C.; Saalfeld, S.; Schmid, B.; Tinevez, J. Y.; White, D. J.; Hartenstein, V.; Eliceiri, K.; Tomancak, P.; Cardona, A. Fiji: an open-source platform for biological-image analysis. Nat. Methods 2012, 9, 676-682. 